\title{
WHERE FROM AND WHERE TO DOES THE MEDICAL BIOLOGY MARCH \\ or HISTORY OF THE BIOLOGY DEPARTMENT OF THE FACULTY OF MEDICINE IN HRADEC KRÁLOVÉ
}

\author{
Miroslav Červinka, František Bartoš, Vladimír Půža
}

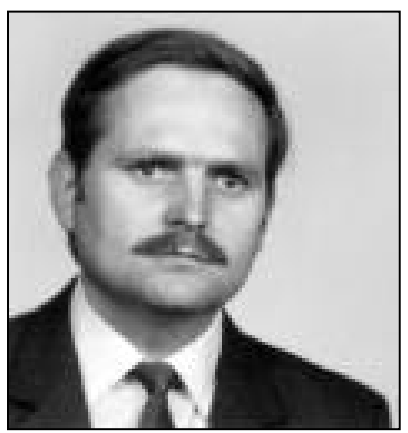

Assoc. Prof. M. Červinka (1950)

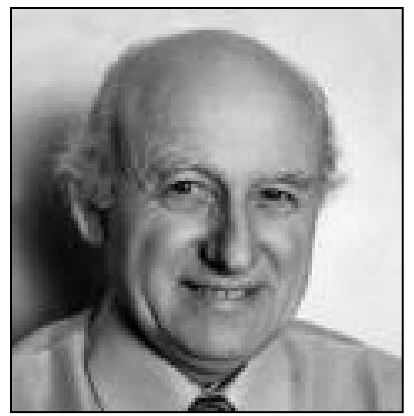

Prof. F. Bartoš (1923)

\section{Acknowledgement}

When I was invited to assemble the detailed history of Biology Department of our Faculty I went for it under the condition that this achievement would represent the result of a team endeavour where also personal observers would render account of the events witnessed by themselves. That is why I addressed Professor Půža and Professor Bartoš. The memories of these two persons thus also represent a part of this publication. Nevertheless, it turned out that neither their memories were able to cover the earliest period of time shortly after the establishment of our Faculty.

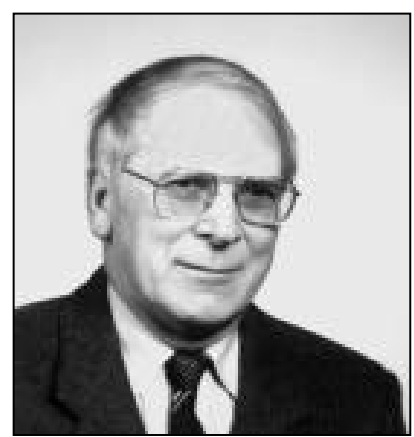

Prof. V. Pִ̊̌za (1926) Searching had to be spread further more. I was then able to gather quite valuable information concerning the very beginnings of Biology in Hradec Králové from Professor Klen and Professor Fingerland, and also from Mgr. Plášilová and Dr. Panoušek. I want to express my gratitude to all those mentioned above as they considerably helped me to fill in the gaps in the history knowledge of mine. Also the historical photographs carefully stored in the archives of Biology Department proved to be valuable and helpful, as well. Author of most of them had been Professor Srb who also deserves my sincere thanks. I dare to hope that our mutual efforts were thus able to create relatively an objective picture illustrating the history of Department of Biology of the Medical Faculty in Hradec Králové.

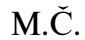

\section{Introduction}

In the history of Biology Department of Faculty of Medicine in Hradec Králové four time periods can be distinguished, correlating with four representatives, who hitherto acted as Heads of our Department within the past fifty years:
The 1st period
$1945-1951$
1952 - 1964
the 2nd period
$1965-1990$
Professor Krajník
Associate Professor
Hluchovský
the 3 rd period
1991 - till now
the 4 th period
Professor Půža
Associate Professor
Červinka

That is why our historical excursion has also been distributed into the four sections. The first three of them should show where the Biology in Hradec Králové has been marching from. As we cannot consider ourselves appropriate enough to evaluate the last time period we rather direct our attention at the prediction of the future trends of biology teaching at the medical faculties. Nevertheless, first of all we would like to briefly mention our Faculty inception.

\section{The role of biologists in the establishment of our Faculty}

At the cradle of the Medical Faculty in Hradec Králové there was no theorist, as the Faculty origin was an 
achievement of the Hradec Králové clinicians, mostly some habilitated head physicians of the county hospital ( $\mathrm{J}$. Bedrna, M.D, A. Fingerland, M.D., B. Janoušek, M.D., P. Lukl, M.D., J. Maršálek, M.D., J. Vavrda, M.D.). But in spite of that also one biologist, and a very outstanding one, supported the foundation of our Faculty, too. His name was Professor Jan Bělehrádek who, before the Second World War, had acted as the Head of Biology Department of the Faculty of Medicine in Prague. As soon as at the beginning of the War he started to negotiate with Professor František Ulrich, M.Sc. and to arrange for this project. In the very first days of May 1945 he goaded Assoc. Prof. Jan Maršálek and Assoc. Prof. Jan Bedrna to initiate the Faculty of Medicine arrangements in Hradec Králové without delay. $\mathrm{He}$ is also well known for laying down the memorandum for President Beneš and Government (4).

\section{Period 1946 - 1951 Professor Bohumil Krajník, M.D., M.Sc.}

The destiny of Department of Biology started to be decided upon a long time before the official teaching started. As soon as by the end of August 1945 there took place the academic staff meeting of the Medical Faculty of Charles University in Prague, when the branch of the Medical School in Hradec Králové had been established. At the same time also the staffing of the new departments had been negotiated. Professor Krajník became an unambiguous candidate for the Head of Department of Biology. His biography has already been elaborated in several papers $(3,5)$, so we are going to point out only some of the most important features from these publications.

Professor Krajník was born on June the 13th, 1895 in Nepomuk near Plzeň. In the year 1914 he matriculated on the Faculty of Philosophy of Charles University in Prague but he enlisted Army in Spring 1915. He was able to go on in his university studies in the year 1918 on the Charles University and since the year 1920 on the University in Brno where he graduated as Natural Sciences Doctor (M.Sc.) in 1923. Within the years 1920 - 1925 he acted as a lecturer on the Veterinary University in Brno. In the year 1925 he left for Bratislava, where he acted as a lecturer on Biological Institute. At the same time he attended the local Medical Faculty, where he successfully graduated in the year 1929. In 1932 he returned to Brno and entered the Department of General Biology of Medical Faculty and habilitated in General Biology. In the year 1935 he left Brno and took up a position on Prague Medical Faculty, Department of Biology of Professor Bělehrádek. In Spring 1938 he rather surprisingly left this faculty and started working in the National Health Institution. He was working in this institute during the whole war time and even after the war, till his taking up the position in Hradec Králové Faculty of Medicine. In the year 1951 he left for Plzeň, where he acted as a Head of Biology Department till his retirement in the year 1959. Professor Krajník died on February the 23rd, 1966 in Plzeñ.
Professor Krajník took part in opening the branch of Faculty of Medicine in Hradec Králové as soon as in Autumn 1945. The first (temporary) dean of this faculty Professor Bohuslav Bouček, M.D. summoned designated department heads to consultate the departments dislocation within the theoretical institutes building. Department of Biology was placed on the first floor where it has been settled ever since.

By the time when teaching in the new Hradec branch was commenced (November the 7th, 1945) no chief of any department was officially appointed yet. Professor Krajník was still an employee of the National Health Institution. On November the 14th, 1945 he was assigned by Ministry of Education and Culture to supply in delivering the lectures and practical trainings in biology, in examining this subject, as well as building up and heading the new Institute of Biology of the newly established branch of Medical Faculty of Charles University in Hradec Králové. This appointment of his also contained a clause stating that for the purpose of these activities he was to be granted a pay leave by the National Health Institution.

Attended by representatives of all other universities, of Charles University and deans of all the faculties of Charles University on November the 25th, 1945 a ceremonial meeting took place where rector of Charles University Professor Bělehrádek declared the branch of the Medical Faculty to be opened. At the same time Professor Krajník had also been inaugurated as the Head of general medical biology department. In mid-December he and his family moved from Prague to Hradec Králové. Nevertheless, he still went on visiting Prague and delivering there some lectures occasionally.

Starting from January the 1st, 1946, the branch in Hradec Králové was headed by Professor Smetánka. Regular teaching began in our faculty in which 381 students took part (1). At the faculty meeting in January 1946 Professor Krajník reported that biology teaching, both lectures and practical trainings, went on without any difficulties.

In addition, by the end of January (26th of January, 1946) Professor Krajník was charged to supply also lectures from histology and embryology, and to examine, organize and temporarily lead this department. In Autumn 1947 the leading of this department was handed over to Professor Vrtiš.

On March 1946 rector of Charles University Professor Bělehrádek submitted a motion to the Ministry of Education and Culture demanding to nominate Professor Krajník as the full professor of the Faculty of Medicine branch in Hradec Králové.

In June 1946 Professor Krajník played an important role during President Benešs visit of our Faculty. By that time President Beneš saw over the Department of Biology, held a speech from the balcony of our department and spent a substantial time speaking to Professor Krajník.

The then orientation of biology teaching may be deduced from the lectures syllabus. It contains the research 
of human constitution, its relation to the heredity, heritability of human diseases, problems of heredity science, contemporary status of the evolution theory, general biology relations to psychology and psychiatry, and basic principles of general biology. The practical trainings of that time were aimed at the learning the structures of plant and animal bodies.

Apart from teaching the main concern of all the employees was represented by organizing their departments. Especially gathering the instruments belonged to highest priorities. Professor Krajník donated a number of instruments of his own and, furthermore, he arranged the presentation of some other ones from the National Health Institution and from the Bata's Hospital in Zlín. By that time Department of Biology also succeeded in obtaining quite a few instruments thanks to the international help programme UNRRA.

Orientation of the scientific research was quite under the influence of Professor Krajník. Since the year 1932, when he delivered the lecture „Research of the constitution and its influence on medicine" in Brno he completely focused his attention on biotypology and genetics. Using the anthropometric techniques for biotypological purposes led him to closer contacts with anthropology. On the biological department the biometric laboratory was organized, which supplied mainly the ready-made clothing factories with its results. Of a practical impact was a particularly developed research of somatotypes changes of apprentices in our city. Professor Krajník's achievements in this field may be taken for a unique and pioneer work and we may thus consider him to be a founder of human constitution theory in our country.

Another direction of the scientific activity of the department was the genetic research that ought to have been performed on several model objects (aquarium fish, maize, Drosophila). This project had not been started as the Medical Faculty was taken over by Ministry of National Defence and Professor Krajník was forced to leave the Faculty.

The general atmosphere on the Department of Biology at that time can be best characterized by memories of Professor František Bartoš, M.Sc., Ph.D. who was one of the lecturers there:

„Professor Krajník was interested in biotypology and genetics. I studied anthropology and zoology. When Professor Krajník needed a lecturer for biotypology he contacted Professor Malý with whom I used to work as a subsidiary assistant. Professor Malý recommended me as the one living in Hradec Králové and thus I started working as a lecturer on the Department of Biology since the January the 1st, 1950. In addition to me and Professor Krajník there were also other lecturers at the Department by that time - Vladimír Balthasar, M.Sc. and Helena Kostková, M.Sc.

Doctor Balthasar came, together with Professor Krajník, from Zlín, where they both worked together during the whole war time in laboratories of research institute and were interested in the foot anthropology in connection with the shoes construction. Nevertheless, Balthasar was a zoologist and his main interests lay in insects. In the year 1951, when Medical Faculty was transformed into the Military Medical Academy, dr. Balthasar left the University and became a Head of the natural scientific department of Museum in Hradec Králové.

Doctor Kostková was initially a botanist from Brno who started studying zoology and together with Professor Krajník worked on the Aschheim-Zondek's test for pregnancy diagnosis on frogs. When performing this test the urine of pregnant women was being injected into the lymphatic sacs of African frogs Xenopus laevis. Professor Krajník wanted the pregnancy tests to be performed on the large scale with cooperation with the Department of Gynaecology and that was why the frog breeding was launched in capacious aquariums in three of the big rooms of the department. Firm CIBA donated to Professor Krajník several couples of these frogs and he began with the first large raising of these animals in Czechoslovakia. When coming on the Department at the beginning of fifties the frog raising was already fully developed. The Xenopus laevis raising is rather difficult so this represented one of the first achievements of this department. After the establishment of Military Academy all the frog farm was liquidated and this course of research abandoned.

The department research orientation was, fully within the intentions of its Head, aimed to anthropological and biotypological surveys of school children. Our department kept quite close contacts not only with elementary schools in Hradec Králové and surrounding places but also with apprentice schools. We gathered basic anthropological data, assessed them statistically and compared them with those of the pre-war period. As soon as by that time we found out that the post-war youth differ from the pre-war ones in body weight and height (as well as also in some other parameters, of course).

Professor Krajník was also indulged in genetics. In the yard of the faculty (where isotope laboratory stands today) used to be quite a large garden where mister Uhlír (laboratory technician-gardener) grew maize, tomatoes and decorative flowers. It was there, where the Mendel-like experiments were carried out. Professor Krajník also intended to crossbreed some aquarium fish so he got widely engaged into the aquaristic. Soon after the Faculty foundation the then Škoda works in Kukleny (about 1946 1948) helped to equip the department laboratories with stands, metal frames for aquariums and fixtures for compressed air feeding. That was why the department had been furnished well for that time. As I recall, Professor Krajník intended to breed also the Drosophila and work with them. From what has been said above one can conclude that he wanted to perform the Morgan's genetics that he got familiar with during his study stay in the U.S.A. in thirties. Unfortunately, at the beginning of fifties the 
political situation in our country was far from being favourable to genetics as there was going on the well known discussion concerning „the linguistics“, the part in which took also Stalin and that had a substantial ideological impact on biological sciences. The era of formal geneticists pursuits began, which involved those who acknowledged Mendel's and Morgan's theories. Professor Krajník belonged to them, too.

During the first years Professor Krajník had no lecturer until February the 1st, 1947, when Vladimír Balthasar, M.Sc., M.A. came. He was an outstanding enthomologist who took over the practical trainings, especially. These trainings from biology were largely of a natural scientific character. They demonstrated mostly different forms of medically important animal groups and also other ones (e.g. demonstrations of protozoans, small Nematodes, frog dissections etc.). Also studies under a microscope were performed and native preparations were prepared. During examinations Professor Krajník had always a microscope at hand and each student had to determine or describe one preparation.

As a human being Professor Krajník was rather wrapped up in himself and he rarely kept company with his co-workers. The instructions and impositions written on pieces of paper and left on the desks in the mornings were his specialities. Nevertheless, for the branch, representing a close relation between the principles of medicine and those of biology Professor Krajník was fully qualified thanks also to his double university education."

\section{Period 1952 - 1964 Assoc. Professor Bohumil Hluchovský, M.D.}

This period of time in the history of our Faculty was very considerably influenced by conversion of the Faculty into the Military Medical Academy. This change had quite a substantial personal impact on the Biology Department. Professor Krajník was unacceptable for Academy and therefore the exchange of Heads of Biology Departments between Hradec Králové and Plzeň was arranged. Professor Krajník was appointed as the Chief of the Department of Biology in Plzeň and Assoc. Professor Hluchovský came to Hradec Králové.

Associate Professor Bohumil Hluchovský, M.D. was born in Benešov on December the 10th, 1900. Within the years 1920 - 1926 he was studying the Faculty of Medicine in Prague and after being graduated he started working on the Biology Department as a lecturer. He was a pupil of Professor Vladimír Růžička, who was the Head of Biology Department of Medical Faculty of Charles University in Prague during the years of the First World War and then in twenties and thirties. Professor Rủžička became a founder of live matter studying from the physical and chemical points of view. He actively experimented (for example, he introduced vital-lethal test by methylene-blue and neutral red), he studied the colloids aging and articulated one of the first gerontological theories, the so called colloids hysteresis. In twenties he used to have two lecturers - Dr. Bohumil Hluchovský and Dr. Bohumil Sekla. Doctor Hluchovský was interested in cytology, Dr. Sekla in genetics. In 1931 Dr. Hluchovský left the department for practical medical activity. Till the year 1945 he was acting as a family doctor in Jičín (see foot note on next page...). After the revolution he was called back to Prague to lecture and examine biology. By the end of the year 1945 he left for Faculty of Medicine in Plzeň, where he worked as a Head of Biology Department. In the year 1951 he habilitated there on the cytological subject „Influence of electric current on the cell."

Together with a change of the Department management also the orientation of scientific work had changed dramatically. Cytology became the most popular. All the then Department workers - lieutenant-colonel Assoc. Prof. Bohumil Hluchovský, M.D., his deputy - major František Bartoš, M.Sc., major Josef Mráz, M.D., captain Vladimír Havel, M.D. and civilian employees Jiřina Mrázová, M.D. and Helena Kostková, M.Sc. were concentrating on the cell. Soon after Dr. Kostková left and her place was taken by Vladimír Půža, M.D. He actually followed his chief, Assoc. Prof. Hluchovský, with whom he started working already in Plzeň.

Workers team of Biology Department was divided into two sections, according to different scientific orientations. One group, headed by Assoc. Prof. Hluchovský, was concerned with the plants cytology. Dr. Půža studied, above all, an influence of different chemical compounds on the mitotic division of the onion roots cells. He also explored the ultrasound and X-rays influence on the same subject. Dr. Bartoš, as the first one in our country, succeeded in growing the plants explantates in tissue cultures in vitro and that was why he was interested mostly in sedimentary cytology. His another sphere of interest was represented by staining with vital dyes and the origin of leucobases.

The second group, led by Dr. Mráz and consisting of Dr. Mrázová and Dr. Havel, studied the influence of the allogenic materials on the development of the chicken germ. They were involved in experimental transfer of birds eggs white and in the influence of this transfer on genetical properties of the coming out chickens. Thus they went on with the work, which Dr. Mráz started on the Department of Biology of Faculty in Prague in the group of Dr. Milan Hašek. Dr. Hašek was a friend of Assoc. Prof. Hluchovský and in the fifties he often visited Biology Department in Hradec Králové. By that time such visits were quite nursed and cultivated.

In the middle of fifties the pressure to orient the research on the military general subjects was ever increasing. The Army showed an interest in treatment possibilities of shot wounds. That was why several workers of this Department started studying the regeneration of skin, subcutaneous tissue, muscles and bone. Skin and connective tissues became the domain of Dr. Bartoš, 
muscles were given to Dr. Půža and bones to Dr. Havel. Nevertheless, solving the questions of tissue regeneration was interesting enough so there were able to mould orientation of some workers for all the rest of their professional lives.

Assoc. Professor Hluchovský was delivering the lectures concerning the general biology and tried to, according to his own ideological orientation, bringing some „new“ elements of Soviet science, as Lysenko, Mičurin, Lepešinská etc. Apart from that he also talked (as much as it was possible) about Mendel and Morgan.

In accordance with the example of Military Medical Academy in Leningrad the practical trainings were directed more zoologically, the representatives of medically important groups were dissected, examples of comparative anatomy were demonstrated. In the sphere of genetics there were seminars led by Dr. Mráz in the spirit of Soviet biology.

In the year 1958 the Military Academy was discharged and Faculty of Medicine in Hradec Králové, apart from small exceptions, returned back into the bosom of Charles University. Dr. Havel left biology to physiology, Dr. Mráz and Dr. Mrázová went over to military radiology. On the contrary, in the year 1957 the Biology Department was entered by Vladimír Srb, M.Sc. who was concerned with cytogenetics. At the beginning of sixties the whole team turned their attention to the studying the dynamism of cells cultivated in vitro by using microphotographies in the phase contrast. Only Assoc. Prof. Hluchovský and Dr. Srb were interested in plant cells. They were intensively concerned with the plant cells osmotic phenomenons, especially after X-ray irradiation. Their results in the sphere of radiobiology of cell membranes in biological experiment were even to be used during the cosmic flights following the successful flight of major Gagarin in the year 1961. Also vegetative experiments tending towards practical radiostimulation of growth and development of onion and garlic and then radioprotection of their storing were continuing. Dr. Půža went on with studying the skeletal muscles, the results of this work are summarized in in his Ph.D. thesis from the year 1962 „Some cytologic problems of skeletal muscles regeneration in mammals." Dr. Bartoš was interested in wound healing and its cytology. He turned his attention mainly on connective tissues proteins, especially the collagen. He studied physical-chemical properties of tendons fibres and their changes due to aging.

Assoc. Professor Hluchovský was very democratic man and a sociable one so the good humour prevailed not only in interpersonal relations but also on the whole Department. Assoc. Prof. Hluchovský used to be also a patient and well experienced experimenter who always had number of good ideas on hand. He was fond of working in the laboratory but liked even better to discuss the problems. Professor Srb remembers: „Not infrequently the Chief picked me up from my office, put me into his car and took me to Chlum. There we climbed the look-out tower, sat down and then there followed the contemplating and thinking of professor Hluchovský. It was an invaluable school for all my life (interwoven with social biology) that taught me how to think within connections, work out the problems even before an experiment was started and afterwards to synthesize the results, seemingly even incoherent.“ Assoc. Professor Hluchovský was well-read, kind-hearted, always approachable, helping everybody and that was why Hradec Králové was gladly being visited by all biologists (Hašek, Sekla, Nečas, Herčík, Štark, Magrot, Křen and others). Assoc. Professor Hluchovský always stressed that Biology of Hradec Králové belongs to the Růžička's cytological school.

On the 9th of October 1964 Associate Professor Hluchovský, the nobleman of spirit, died.

Note:

„During the war I used to go visiting my grandma in Jičín and am still remembering a small notice on one of the houses: Bohumil Hluchovský, M.D., family doctor, emeritus assistant of Professor Růzickka. By that time it had not even come to my mind that in a few years I would meet him and become his pupil." (Professor Bartoš).

\section{Period 1965 - 1990 \\ Professor Vladimír Půža, M.D., Dr.Sc.}

After Assoc. Professor Hluchovský died Assoc. Professor Vladimír Půža, M.D., Ph.D. became the Head of Department of Biology in the year 1965. He habilitated in the year 1964 by thesis „Amitotic division observed in animal cells in vivo.“

He was born on February the 26th, 1926 in Prague, in the year 1945 he started studying the Faculty of Medicine in Prague. In the year 1948 he changed the faculties and passed to Plzeñ where he graduated in the year 1951. Already during his studies he worked as a lecturer under the guidance of Assoc. Prof. Hluchovský on the Department of Biology. In the year 1952 he followed Assoc. Prof. Hluchovský and came to Hradec Králové Medical Faculty. The more detailed information can be obtained in Lékařské zprávy LF UK Hradec Králové (2).

The change of the Department Head did not show much as far as the scientific activity of Department was concerned. In the middle of sixties the department went on in the hitherto research trends: study of cytological processes dynamism, connective tissues in connection with aging studies, and cytogenetical research.

Assoc. Prof. Půža, when studying the muscle regeneration, met with an interesting problem of nuclei multiplying in muscle syncytium. In order to solve this problem there was necessary in the department to introduce the growing of mammals cells in vitro, namely of explantates from the healing muscle wounds and later also on the cells from so called stabilized cell lines. In the year 1965 Miroslav Hroch, M.Sc. came in the Department and 
as a former virologist he was very well able to exploit his experience with growing the microorganisms also in growing the cells in vitro.

For following the dynamism of nuclei division in muscle syncytia the microphotography was not sufficient any more, so Assoc. Prof. Půža introduced a very demanding method of time-lapse microcinematography. This achievement had determined the scientific orientation of our Department for several decades. Among the biology departments in Czechoslovakia our Department gained its position namely in dynamics of cell movements studies and dynamics of cell organelles changes (e.g. nucleolus).

By that time Dr. Bartoš went on with his collagen studies. In the year 1967 he started a number of years lasting cooperation with Dr. Jiří Kanta who entered our Department by that time.

Dr. Srb was paying his attention mainly to animal cell studies. He worked out a special methodology for following the disorders of cell division and thus laid the basis for cytogenetical studies.

Assoc. Professor Půža started making use of cells cultivated in vitro for assessing the toxicity of implanted materials, above all in stomatology. Thanks to the understanding of Professor Sazama, by then the Head of Department of Stomatology, and in cooperation with Professor Sícha and especially with Professor Novák, he put down quite a number of studies concerning the cytotoxicity. For this purpose they took over and adapted several methodologies, some of which they invented themselves.

Very important period started in the year 1969 when Pharmaceutical Faculty of Charles University started to be founded. When calling this faculty into existence it was necessary to lean on the experience of experts and that was why most of the members of Biology Department, namely Assoc. Professors Půža, Bartoš and Srb, were taking part in teaching on this new Faculty. Assoc. Professor Půža was charged to coordinate the biology lecturing on the newly arising Department of Pharmaceutical Propaedeutic. By that time Božena Červenková-Višňovská, M.D. and Marie Elgrová-Kozáková, M.D. entered our Department. Both of them also started teaching.

In the year 1969 one very outstanding tradition of our department started. The first international colloquium concerning the cell dynamism followed by microcinematography took place. These scientific meetings were later repeated every three years under the name CYTOCINEMA. Such a tradition still goes on, the last meeting was held in the year 1996.

Department of Biology went through quite a complicated period at the beginning of seventies, during the years of „normalization“. Recently habilitated Assoc. Prof. Bartoš left our Department for the Department of Biology of the newly established Pharmaceutical Faculty of Charles University. From the political reasons Assoc. Prof. Srb had to leave, as well. Jan Gayer, M.D. was admitted instead of him and stayed working on our Department till the year 1976 when he left for Department of Pediatrics of the University Teaching Hospital in Hradec Králové. In the year 1975 Miroslav Cervinka, M.Sc. and in the year 1976 Jana Kolářová, M.D. joined the staff. This configuration of the team worked together till the beginning of nineties, though also some others joined the Biology Department. Most of them worked here for short periods of time (Dr. Lacinová, Dr. Bařinková, Dr. Lesná). Mentioned should be an important help of a number of auxiliary scientific hands - Ladislav Hanousek, Pavel Žáček, Miroslav Brtko, Jindra Rondiaková, Štěpánka Dočekalová, Radka Nečasová and Zdeněk Fiedler. All of them are now successfully working on the departments of the hospitals in Hradec Králové and elsewhere.

The scientific orientation of our Department in the late seventies and eighties was given by solving the national research project, which was aimed at the cells differentiation (coordinator Professor O. Nečas, M.D., Dr.Sc.). As this time Dr. Hroch studied functional - morfological changes in the nucleolus in the cells cultivated in vitro, this topic was subject of his Ph.D. thesis in 1973. During this project the differentiation in muscle syncytia was studied first. In later years the research became directed at the myoblasts fusion study. At the end the study resulted in artificially induced cells fusion. For rather a long period of time the cells fusion induced by Sendai virus was used, afterwards also polyethylene glycol induction was exploited. This subject was also published in the habilitation thesis by Dr. Hroch in the year 1976 (Interaction of cells in populations cultivated in vitro) and by Dr. Červinka Ph. D. thesis in the year 1980 under the name „Fusion of cells in vitro.“

At that time our department also started another research line - study of health materials toxicity. This sphere of activity was rather dependent on a close cooperation with some other departments (namely with the Department of Stomatology) of our hospital and resulted in many original scientific studies. This research area made our Department well known throughout the whole republic. Without exaggerating it may be easily stated that within the frame of all the country our department is still the only one that for a long time systematically concerns with the toxicity of various materials used in health care. The substantial part of these results were summoned up in the doctor dissertation thesis of Assoc. Prof. Pưža under the name „Dynamic follow up of changes in vitro cultivated cells caused by tough health materials“, which he defended and thus gained Dr.Sc. degree in 1985.

Another reorganization occurred in 1986 when on the whole faculty several departments were joined together. Department of Biology was united with Departments of Anatomy, Histology and Embryology, thus forming one big Department of morphological sciences. As the head of this new department was appointed Assoc. Prof. Půža who still led also the Department of Biology. Department of Anatomy was led by Assoc. Prof. Pařizek, Department of 
Histology by Assoc. Prof. Němeček. This kind of departments union showed to be completely artificial and immediately after the 1989 revolution was dismissed.

During the eighties a new trend in the research orientation of our Department started showing - origin of the molecular biology. Some individual problems are having been consistently followed by our Department since the year 1985 - at the beginning using cells fusion in vitro for genetic information transfer, later on by interactions of different matters with DNA. From this point of view we can consider our participation in the development of a new cytostatic agent cisplatin as an important one. For a certain time period our Department took part, together with the Military Medical Research and Postgraduate Institute, in military project studying antidotes.

Proceedings of appointment for professorship of Dr. Půža was opened in the year 1988 and on Spring 1990 he was assigned to Professor of General Biology.

\section{Period 1991 - till now Assoc. Professor Miroslav Červinka, M.D., M. Sc., Ph.D.}

In Autumn 1990 Associate Professor Miroslav Červinka, M.D., M.Sc., Ph.D. was appointed as the Head of Department of Biology. In the year 1992 Professor Pưža retired and in 1995 did also Assoc. Prof. Hroch, both still having part-time jobs on our Department. The generation alteration was completed within the two recent years when our Department was joined by several new graduates: Mgr. E. Rudolf, J. Peychl, M.D., M. Šenkeříková, M.D. These staff changes were rapidly projected into a new style of both the scientific activity and teaching. In the research work the experience with cytotoxicity measuring in vitro led to effort to study even the cellular and molecular mechanisms of cell death, observing especially apoptosis dynamics, including the use of DNA analysis. Even some new themes appeared - studies of toxicity of chromium compounds as an important factor of environmental pollution, and also the study of tumor cells invasivity in vitro (in cooperation with the Gerontometabolic Department of Professor Zadák). Eminent changes appeared also in teaching activities. An important component of lectures today is represented by gene engineering and molecular biology - starting from the methodology basics, including the clinical use, as well as its relevant ethical problems. We have achieved an improvement in the practical trainings by creating the molecular biology laboratory and including the topics from this sphere into the practical trainings. Nevertheless, this all represents already the presence of our Department and does not belong into the historical reminiscence any more.

\section{Quo vadis, Biology?}

In this last chapter one of the authors (Miroslav Cervinka) tries to contemplate an importance of general biology teaching on the Faculty of Medicine at present and implies a future destination and perspectives of this medical branch.

„First of all it seems necessary to define briefly the traditions of the Czech biology that I acknowledge. The general biology was introduced as a subject on all the medical schools in Austria - Hungary in the year 1899. The one hundred years history of general biology on the medical faculties was started by Professor Eduard Babák, who was the first who attempted the habilitation in the sphere of general biology. Unfortunately enough, unsuccessfully, so he habilitated afterwards in physiology. Apart from that he formulated and defined the aims of general biology in the year 1901 as: „Knowledge and understanding the phenomena vital, inasmuch as the conditions buried in and outside the organisms." The first person habilitated from general medical biology was Professor Růžička in the year 1905, who formulated the aims of general biology in this way: „To the doctors to be the survey of general vital phenomena to offer, because man, as the component of living nature that he is, cannot be beyond them." Following Professor Růžička, the Head of Biology Department became Professor Jan Bělehrádek who stressed so called integrated biology - biologia generalis, founded on the holistic principles. I dare to think that my vision of general medical biology is represented by a point of intersection of all three convictions of these representatives.

On the practical level there stands a question: why the general biology should be taught on the medical faculties? We, biology teachers, are able to feel the answer at least by intuition. Nevertheless, on this score following basic questions ought to be sometimes given and an answer should be formulated.

\section{What to teach?}

There can be heard the first question: what to teach as the knowledge, skill and attitude are concerned, what is the pregraduate and what is the postgraduate matter? For the orientation purposes there follows a brief survey of our contemporary teaching spheres of biology on our faculty:

cell theory

cell structure and function

cell reproduction - cell cycle

cell and environment interaction

cell differentiation

cell death - cell pathology

molecular aspects of biological processes

storing and transfer of genetic information

reparation of DNA damage

expression of genetic information

technology of recombinant DNA - gene engineering

molecular diagnostics

ethics of gene manipulation 
basics of organisms genetics

basics of clinical genetics

immunogenetics, transplantation immunity

malignant cell transformation, tumor genetics,

tumors and environmental influence

populations genetics

evolution theory - life origin, evolution principles, man evolution

Note:

Contents of biology subject on individual medical faculties in our republic varies substantially. On some faculties also the lectures concerning ecology are being included. In some other the molecular biology is included as a special subject.

\section{How to teach?}

Lectures and seminar courses represent the basic forms of teaching. Nevertheless, the education should also include some practical aspects. This kind of an approach is, unfortunately, very expensive. But the undergraduate students should master and practically try such basic techniques as DNA molecules isolation from the human cells, DNA separation, electrophoresis, PCR etc. The biology teaching on the medical faculties cannot be reduced to technical details of the records of individual molecular biological courses.

The basic principle in teaching medical biology is the endeavour to integrate cognition and combine individual knowledge levels - the molecular, cellular, organism and population ones. The second feature is characterized by the consistent integration of a morphological and functional approaches. These two aspects cause biology to be difficult and unpopular among the students.

To find the optimum and harmonic relation between the clinical application examples, that are of a certain motivation nature, and well-balanced information concerning the uniform structures of all organisms, which means an integrated view of life, requires quite a high skill. This complex character needs to be nursed, though being rather demanding on the first year students who are accustomed to more isolated approach.

There exists also another specificity of our subject. It is a rather difficult searching for harmony between basic knowledge and the newest up-to-date pieces of information that appear each year in an enormous quantity. Many of them penetrate into the subconsciousness of wide public and there cannot be omitted or not commented. Biology should also contribute to demythologizing the gene manipulations.

In many basic biological processes we come close to the ethical limits of justifiable processes (organism cloning, gene manipulations, presymptomatic diagnostics, transplantations etc.). Therefore also the ethical and legal aspects have to become an integral part of the general biological view.

\section{Whom to teach?}

What kind of physicians need to know the basic principles of molecular biology? The only conclusion states that teaching should be aimed towards all to be doctors the basic course has to be obligatory for all doctors. The physician of the first contact (family doctor) belongs to the experts who will be in daily contact with public and, besides that, who also have some educational and cultural duties. Their education must ensure them to be able to fulfil their tasks. From this point of view the biology teaching has to include even the yet unsolved questions, the scientific, as well as, and above all, the ethical ones. Their education must prepare them in such a manner that they will be able to comment and answer questions appearing in press or TV.

For those showing a deeper interest in knowing special aspects there has to exist a differentiated offer of optional courses. Within our city Hradec Králové this offer should be common for Faculty of Medicine, Faculty od Pharmacology and also Military Medical Academy and it ought to cover clinically, theoretically, methodically and preventively orientated courses.

\section{Who should teach ?}

According to the interdisciplinar character of general medical biology it is suitable when a part in teaching is being taken by physicians, biologists and pharmacists, and specialized cytologists, geneticists and molecular biologists. This also contributes to the interdisciplinary approach.

\section{When to teach ?}

The teaching has to be done on several levels. The basic level of studying ought to be somewhere in the 1st or 2 nd year. Basic principles have to be elucidated, though rather simply, and then, gradually during the course of further studies, these basics can be expanded and made more accurate. Such a system has to be very flexible as the knowledge is being generated in an unbelievable pace. Biology is the subject with the fastest dynamism.

When to write down this subject into curriculum, what should be an obligatory and what an optional part, how many hours of lectures, what is the best ratio between lectures and practical trainings?

The last but never ending task is represented by coordination and communication of themes delivered with consequential subjects (histology, biochemistry, cellular physiology, immunology, microbiology, cell pathology, hygiene and preventive medicine and many others).

It is not possible to remain to be the biological theorist only. To teach biology properly means also not to separate science from teaching even in undergraduate studies. Meeting this goal is nowadays being restricted by the lack of finances. But in spite of that, biology has to give to the future doctors a basic orientation and clearly determine, 
which approach can be considered as scientific one and which not. At present, when some aspects of post-modern vagueness quickly gain a vast popularity, this task becomes very important, indeed.“

\section{Acknowledgement}

The authors wish to express their deep gratitude to Associate Professor Karel Šmejkal, M.D., Ph.D. for the translation of this article.

\section{References}

1. Bouček B. Two years existence of the faculty branch of Hradec Králové (1945-46 and 1946-47) (in Czech). Brushproof of non-edited print: 224.

2. Červinka M. Professor Vladimír Půža, M.D., Dr.Sc., 70 years old (in Czech). Lékařské zprávy LFUK Hradec Králové 1996;41:63-64.
3. Frýdl Z. Professor Bohumil Krajník, M.D., M.Sc., 65 years old (in Czech). Praktický lékař 1960;40:623-624.

4. Panoušek V. Why was it just Hradec Králové? In: Group of authors. Medical Faculty Charles University in Hradec Králové 1945-1995 (in Czech). Edition 1. Publisher ATD, 1995:161.

5. Strouhal E. One hundred years since the birth of Professor Bohumil Krajník, M.D., M.Sc (in Czech). Acta Universitatis Carolinae Pragensis 1995;35:89-98.
Doc. MUDr. RNDr. Miroslav Červinka, CSc., Department of Biology, Charles University, Faculty of Medicine, Šimkova 870, 50001 Hradec Králové, Czech Republic. 